\title{
(RETRACTED) MENIMBANG DAKWAH DALAM KUBUR SEBAGAI DAKWAH INOVATIF DI ERA MILENIAL
}

\author{
LUKMAN AL FARISI \\ Fakultas Dakwah dan Komunikasi \\ Universitas Islam Negeri (UIN) Sunan Ampel Surabaya \\ Email : lukmanalfarisi56@gmail.com
}

\begin{abstract}
:
This article tries to analyze the phenomenon of da'wah in the grave carried out by several religious leaders in the last five years. Da'wah which had been predicted as one of the innovative da'wah, is now no longer seen done by some of the perpetrators. So preaching with a model like this needs to be reconsidered. For this reason, this paper outlines whether this propaganda is still innovative at this time, especially in millennial circles. To find this out, the authors use Rogers' perspective on innovation. This perspective will look in more detail, whether propaganda in this way is an innovative propaganda. How if applied to millennial today, and how then Islam views an innovation. These issues are described in the discussions in this article, to answer some of the questions that arise, to later be a reflection of the missionary journey in Indonesia.
\end{abstract}

Keywords : Da'wah, Grave, Innovation, Millennial

\section{PENDAHULUAN}

Dakwah dalam kubur menjadi salah satu metode dakwah yang digunakan oleh beberapa Ustaz. Setidaknya ada beberapa tokoh yang ikut serta menggunakan cara berdakwah dengan model seperti ini. Sebut saja Ustaz Muzammil, salah satu tokoh agama asal Bengkulu. Ada pula Ustaz Nur Muhammad alisa Gus Nur, KH Masykur M. Alfaruq yang merupakan pengasuh Pondok Pesantren Nurul Ikhlas Tulang Bawang, Lampung, hingga Ustaz Mohaedi Anwar Temanggung.

Melihat banyaknya pendakwah yang menggunakan metode itu, menjadikan fenomena tersendiri di dunia dakwah. Sebab metode ini sempat menjadi salah satu metode yang cukup menarik perhatian pada lima tahun terkahir. Selain unik, dakwah dengan cara seperti ini juga terbilang anti mainstream dalam dakwah. Sebab, pada umumnya, dakwah dilakukan melalui cara-cara konvensional, seperti ceramah, khutbah hingga pidato, yang digelar di masjid-masjid, majelis taklim, hingga di kegiatan-kegiatan sosial, termasuk dalam

\footnotetext{
${ }^{1}$ Basit, Abdul, Dakwas Cerdas di Era Modern, Jurnal Ilmu Komunikasi, 2013, Volume
} $03 \mathrm{~h} 1$. 
pernikahan. $^{2}$

Namun dakwah dalam kubur seperti memberi ruang baru. Sebab jika biasanya ceramah agama dilakukan di ruang-ruang terbuka, di atas panggung dan sebagainya, kini ceramah-ceramah itu justru dilakukan di dalam tanah, layaknya jenazah yang sudah di makamkan. Tentu dalam prosesnya terbilang agak menyeramkan, ekstrem, berbahaya dan tak bisa dilakukan oleh sembarang Ustaz. Perlu keahlian khusus untuk menerapkan model dakwah seperti itu. Sebab jika salah, tentu berakibat fatal.

Penggunaan dakwah dalam kubur oleh beberapa Ustaz itu tentu bukan tanpa alasan. Dakwah seperti itu dianggap sebagai salah satu dakwah yang inovatif. Alasannya, dakwah seperti ini tak pernak dilakukan oleh beberapa tokoh agama sebelumnya. Sehingga hal ini merupakan hal baru, dengan tetap mengadopsi dakwah konvensional yaitu ceramah. Yang membuatnya berbeda adalah, ceramah itu justru dilakukan dengan cara yang tak biasa. Selain itu, materinya juga lebih fokus pada masalah-masalah kematian.

Di sisi lain, dakwah seperti ini nampaknya saat ini perlahan mulai pudar. Sulit sekali beberapa Ustaz yang telah disebut penulis sebelumnya terlihat berdakwah dengan cara seperti itu. Itu artinya, metode seperti itu perlahan mulai ditinggalkan, meski awalnya terbilang sangat menghebohkan dunia dakwah. ada sejumlah dugaan-dugaan yang mungkin menjadi salah satu faktor mengapa dakwah dengan cara seperti itu kini tak lagi dilakukan. Sehingga metode ekstrem itu mulai tenggelam. ${ }^{3}$

Pertama, dakwah dalam kubur lebih banyak fokus pada materi tentang kematian. Hal ini mungkin cocok dân menjadi inovasi tersendiri bagi masyarakat, dengan umur yang sudah tua hingga renta. Sebab, segmentasi dakwah dalam kubut adalah menyentuh perasaan, merenungi amal perbuatan dan bagaiman kelak saat dimakamkan. Sentuhan rohani dalam dakwah ini mungkin lebih mengena, daripada sekedar berceramah, tanpa embel-embel kubur dan kematian. Sementara hal-hal yang berbau kematian tentu tidak diminati oleh kalangan milenial seperti saat ini.

Kedua, masuknya era milenial tentu berbarengan dengan hal-hal yang berbau teknologi, kecanggihan mesin, dan sebagainya. Milenial lebih dekat dengan hal-hal seperti itu. fenomena yang terjadi saat ini, tokoh-tokoh agama juga turut bertransformasi cara dakwahnya dari konvensional menuju digital. Hal itu terlihat dari banyaknya tokoh agama yang kini menggunakan berbagai platform media sosial berbasis internet sebagai salah satu media yang digunakan dalam

${ }^{2}$ Wahidmurni, Pemaparan Metode 45Penelitian Kualitatif Makalah Dosen Fakultas Ilmu Tarbiyah dan Keguruan, UIN Maulana Malik Ibrahim, Malang, 2017. h 33.

${ }^{3}$ Tajuddin, Yuliyatun, Walisongo Dalam Strategi Dakwah, Jurnal Addin, 2014, h 45. 
berdakwah. Contoh sederhana, kini ceramah-ceramah yang dilakukan di masjidmasjid, musala-musala dan lokasi lainnya, mulai diintegrasikan ke media sosial.

Ketiga, penerapan dakwah dalam kubur tentu akan memakan banyak tempat. Sebab, dakwah dengan cara ini membutuhkan lahan yang dijadikan lokasi sang Ustaz untuk menyampaikan pesan dakwahnya. Sementara di beberapa masjid, musala dan sebagainya, tak memiliki cukup banyak lahan yang tersedia. Lebih-lebih di daerah perkotaan, dengan lahan yang terus menerus berkurang. Sehingga dakwah dalam kubur merupakan salah satu dakwah yang terlihat cukup sulit jika harus dilakukan di daerah perkotaan dengan lahan yang terbatas.

Keempat, problem manusia yang relatif berkembang. Pada dasarnya dakwah haruslah menyentuh padal masalah-masalah yang dihadapi manusia. Baik menyangkut dirinya sendiri, atau dalam lingkungan sosialnya. Sayangnya, dakwah dalam kubur lebih fokus pada masalah kematian, bagaimana mengemas hidup manusia agar selamat dalam siksa neraka. Sehingga sasaran masalahnya berfokus pada kehidupan di akhirat kelak.

Dari beberapa analisa ini, maka dakwah inovatif pada dakwah dalam kubur perlu untuk dipertimbangkan kembali. Apakah masih relevan dengan keadaan saat ini, atau justru memang seharusnya untuk ditinggalkan oleh pada pelakunya. Penulis memiliki keseimpulan awal, jika dakwah dalah kubur sudah tak lagi relevan dengan kondisi dan situasi yang terjadi saat ini. Namun, untuk mengetahui apakah dakwah ini merupakah dakwah yang masih inovatif atau justru usang dan tak lagi masuk dalam kategori dakwah inovatif.

\section{PEMBAHASAN}

\section{Dakwah Dalam Kubur}

Dakwah dalam kubur merupakan salah satu cara dakwah yang dilakukan oleh beberapa Ustaz. Mereka di antaranya seperti salah satu tokoh agama asal Bengkulu, yaitu Ustaz Muzammil. Selainnya ada pula Ustaz Nur Muhammad alisa Gus Nur, Pengasuh Pondok Pesantren Nurul Ikhlas Tulang Bawang, Lampung yaitu KH Masykur M. Alfaruq, hingga Ustaz Mohaedi Anwar Temanggung. Beberapa pendakwah tersebut melakukan ceramah dengan cara dikubur di dalam tanah layaknya jenazah yang dimakamkan. Sebelum proses itu berjalan, serangkaian acara yang disyari'atkan oleh islam juga dilakukan, seperti mengafani, menyolati hingga memakamkannya.

Misalnya saja dakwah dalam kubur yang dilakukan oleh KH Masykur M. Alfaruq alias Gus Faruq. Menurutnya, apa yang dilakukannya tersebut dengan cara berdakwah dengan cara dimakamkan merupakan salah satu cara untuk lebih 
dekat dengan tuhan. ${ }^{4}$ Seperti ucapannya berikut ini:

"Dakwah Kubur ini adalah salah satu cara mendekatkan diri kepada Allah SWT, bahwa kita dihadapan Allah hanya sebutir debu yang tanpa campur tangan kuasa-Nya kita bukan apa-apa dan bukan siapa-siapa, ketika kita dihadapkan pada liang lahat berukuran $1 \times 2$ meter lubang di mana merupakan tempat peristirahatan terakhir kita", (Muhammad Faizin, NU Online:2019)

Hal yang sama juga dilakukan oleh Ustaz Nur Muhammad alisa Gus Nur. Penceramah tersebut juga melakukan serangkaian layaknya jenazah seorang muslim hendak dimakamkan. Dimana, setelah proses mengkafani dilakukan, selanjutnya Gus Nur akan dibawa ke liang lahad. Disana, Gus Nur ditutup dengan papan untuk kemudian ditutup dengan tanah. Kendati demikian, sebelumnya di dalam liang lahad itu sudah disediakan dengan mikrofon. Alat itu digunakan oleh Gus Nur untuk menyampaikan dakwahnya selama kurang lebih 1,5 jam di dalam tanah.

Ada pun salah satu kutipan ceramahnya saat berada di dalam kubur sebagai berikut:

"Akan datang suatu saat lidah menjerit memohon pertolongan dan syafaat Nabi Muhammad SAW saat di akhirat. Allah itu indah menyukai segala sesuatu yang indah menerima segala sesuatu, tidak mau menerima ajaran di luar ajaran Allah. Maka dari itu bertobatlah wahai manusia. Orang yang mengingat Allah mengalir air matanya" (Saiful Arief, Faktualnews.co:2017) ${ }^{5}$

Ceramah dengan cara seperti itu rupanya cukup membuat masyarakat takjub. bahkan dalam berita yang ditulis oleh Faktualnews.co itu, jamaah terlihat menangis tersedu-sedu. Jika melihat kondisi seperti itu, maka dakwah dalam kubur dapat menjadi salah satu cara yang cukup efektif. Terutama dalam menyentuh hati nurani masyarakat sebagai obyek dakwah yang dilakukan. Kendati demikian, walaupun caranya cukup ekstrem, tak ada hal-hal yang berkaitan dengan mistis. Substansi sama dengan penceramah yang lain, hanya cara saya berdakwah mungkin yang beda. Saya kira sama dengan Rhoma Irama yang menggunakan cara dakwah dengan lagunya. Saya gunakan dengan hasil kreasi saya ini (Saiful Arief, Faktualnews.co:2017).

Namun demikian, dakwah seperti ini sudah dilakukan sejak lama. Walaupun pada prosesnya dakwah seperti merupakan salah satu dakwah yang cukup inovatif, namun Gus Nur mengakui, jika dalam prosesnya perlu

${ }^{4}$ Muhammad Faizin, NU Online 2019.

${ }^{5}$ Saiful Arief, Faktualnews.co:2017 
pembaharuan. Awalnya, metode ini dipilih lantaran merasa kesulitan dalam mengajak masyarakat untuk turut hadir dalam kegiatan-kegiatan pengajian.

Alhasil, rupanya metode tersebut berhasil menarik perhatian masyarakat hingga ikut serta dalam pengajian. Tentu ada beberapa alasan mengapa banyak masyarakat yang tertarik untuk datang dalam pengajian dengan metode seperti itu.

Hal itu dapat terjadi manakala dakwah dilakukan dengan cara yang berbeda dari biasanya. Dalam konteks dakwah dalam kubur, tentu arah pesannya adalah mengingat kematian. ${ }^{6}$ Biasnaya, dalam budaya umat muslim di Indonesia, salah satu cara mengingat kematian adalah melalui ziarah kubur. Baik kepada makam-makam keluarga hingga makam Ulama yang dianggap sangat berjasa. Abd Aziz dalam artikelnya yang berjudul Ziarah Kubur, Nilai Didaktis dan Rekostruksi Teori Pendidikan Humanistik menyimpulkan, bahwa Tradisi kubur sebagai bagian dari bentuk dakwah Islamiah mempunyai nilai dan fungsi didaktis (Abd Aziz, 2018:58). Salah satu nilai didaktis itu adalah sebagai salah satu transformasi mengingat kematian dan semangat kebaikan.

Artinya, kubur atau hal yang berkaitan dengannya dapat dijadikan sebagai salah satu bentuk mengingat kematian. ${ }^{7}$ Aziz menjelaskan, kendati bagi sebagian orang bahwa kamatian merupakan hal yang dianggap mengerikan, namun kematian dapat menjadikan manusia lebih bersemangat dalam melakukan kebaikan. Konsep dasar inilah yang mungkin dijadikan oleh bebarapa pendakwah sehingga menggunakan metode dakwah dalam kubur. Jika melihat apa yang dilakukan oleh Gus Nur dan beberapa penceramah lainnya, dengan metode ini membuat jamaah dakwahnya menangis tersedu-sedu, tentu sesuai dengan apa yang dikemukakan Abd Aziz tersebut.

Di Indonesia sendiri pada dasarnya, mendengar kata kubur bukan sesuatu yang menakutkan. Bahkan istilah itu merupakan salah satu budaya yang melekat dalam tatanan kehidupan masyarakat di Indonesia. Dari yang awalnya sebagai adat tradisi untuk mengirimkan doa kepada keluarga yang telah mendahuluinya, namun lama-kelamaan kemudian menjadi obyek wisata khusus. Bagi sebagian organisasi masyarkat (Ormas) seperti Nadhdlatul Ulama, tradisi ziarah kubur tak pernah lepas dari tradisi anggotanya. Bahkan, ziaran merupakan salah satu anjuran yang harus dilakukan (M. Ali Zainal Abidin, NU Online:2019). Pendektaan semacam ini yang kemudian menjadi sumber motivasi pada Ustaz untuk mentransformasi mengingat kematian dengan xara ziarah kubur, menjadi salah

6 Abdul Aziz (2018). Ziarah Kubur, Nilai Didaktis dan Rekonstruksi Teori Pendidikan Humanistik, 13 (1), 66.

7 Abdul Aziz. (2018). Ziarah Kubur, Nilai Didaktis dan Rekonstruksi Teori Pendidikan Humanistik, 13 (1), 87. 
satu metode dakwah dengan cara berdakwah dalam kubur.

Dalam penelitian yang dilakukan oleh Desy Ana Roifa, salah satu mahasiswi UIN Walisongo Semarang yang berjudul Dakwah dalam Kubur, Studi Fenomenologis Metode Dakwah Kiai Mohaedi Anwar, penelitian itu menyimpulkan, bahwa dakwah yang dilakukan oleh Kiai Mohaedi Anwar tersebut merupakan dakwah Mauidhoh Hasanah. Dimana, dalam prosesnya, ada dua metode yang digunakan dalam dakwah dalam kubur tersebut. Yaitu menggunakan metode ceramah dan metode drama (Desy Ana Roifa, 2018:68). Melihat kesimpulan itu, sudah barang tentu penggabungan itu merupakan salah satu inovasi baru dalam dakwah. Sebab, metode penggabunagan antara ceramah dan drama sangat jarang sekali nampak. Terlepas apakan penggabungan tersebut memiliki resiko tinggi atau tidak, namun metode sepertu rupanya telah berhasil menarik perhatian masyarakat yang menjadi jamaah, sekaligus berhasil menunjukkan bahwa trobosan yang terlihat ekstrem tersebut juga perlu dilakukan. $^{8}$

Dalam prosesnya, Desy Ana Roifa menjelaskan, jika metode ceramah sendiri dilakukan dengan cara memberikan nasehat agama kepada para jamaah yang hadir. Sementara pada proses dramanya, dengan memberikan gambaran proses kematian seorang muslim. Dimana pada ritualnya, jenazah akan dikafani, diusung melalui keranda untuk kemudian dibawa ke liang lahad untuk dikuburkan alias dimakamkan. Penemuan Desy rupanya tak berhenti disana, dia menemukan, jika jamaah yang hadir dalam pengajian dengan cara seperti itu tak hanya satu atau dua orang, akan tetapi mencapai puluhan hingga ratusan orang. Dakwah dalam kubur tidak hanya dihadari oleh orang tua akan tetapi juga kalangan pemuda (Desy Ana Roifa, 2018:68). Apakah metode seperti masih memerlukan sentuhan-sentuhan di dalamnya, ataukah cara ini sudah cukup untuk terus dilakukan oleh para penceramah, hal ini tentu perlu ditinjau kembali melalui berbagai perspektif. Terutama kaitannya dengan sebuah inovasi.

\section{Meninjau Inovasi Dakwah Dalam Kubur}

Dakwah dalam kubur sudah menunjukkan bagiaman cara tersebut cukup sukses dilakukan. Bukan hanya pada tataran bagaiaman pesan dakwah itu tersampaikan kepada jamaah yang hadir, namun juga bagaimana dampak saat poroses dakwah itu berjalan. ${ }^{9}$ Kendati demikian, setiap dakwah yang dilakukan

8 Desy Ana Roifa, Dakwah dalam Kubur, Studi Fenomenologis Metode Dakwah Kiai Mohaedi Anwar. Skripsi UIN Walisongo. Semarang. 2018 h 68

${ }^{9}$ Fakhrurroji, Moch. (2010). Dakwah dan Inovasi Media, Peluang dan Ancaman Media Global Atas Dakwah Islam, Jurnal Komunika. Vol 4 No.1 
melalui cara-cara yang tak biasa tetap diperlukan untuk ditinjau ulang. Apakah dakwah tersebut masih dalam tataran yang inovatis atau justru saat ini memerlukan sentuhan-sentuhan tambahan.

Syafrudin, Asrul dan Mesiono mengutip (Wijaya, 1992:9) mengenai inovasi, yang menjelaskan, bahwa (Innovation) adalah upaya memperkenalkan berbagai hal yang baru dengan maksud memperbaiki apa-apa yang sudah terbiasa demi timbulnya praktik yang baru baik dalam metode ataupun cara-cara bekerja untuk mencapai tujuan (Syafaruddin, Asrul dan Mesiono, 2012:23-24). Artinya, inovasi merupakan hal baru yang dilakukan untuk tujuan-tujuan tertentu. Sementara Kuniyoshi Urabe, menjelaskan, bahwa:

"Inovasi merupakan setiap kegiatan yang tidak bisa dihasilkan dengan satu kali pukul, melainkan suatu proses yang panjang dan kumulatif, meliputi banyak proses pengambilan keputusan, mulai dari penemuan gagasan hingga ke implementasian nya di pasar". (Studiilmi.com, Pengertian Inovasi dan 8 Hal Penting Menjadi Inovatif)

Sementara itu, masih ada salah satu tokoh yang memiliki pengertian mengenai inovasi bahkan pada tataran perangkat-perangkatnya. Salah satu tokoh tersebut adalah Everett M Rogers. Salah satu teorinya yang terkenal mengenai inovasi adalah teori difusi inovasi. Rogers menjelaskan, bahwa difusi inovasi adalah "Diffusion is the process by which an innovation is communicated through certain channels over time among the members of a social system" (Everett M Rogers, 1983:17). Jika artikan, bahwa inovasi merupakan salah satu proses bagaimana suatu inovasi dikomunikasikan lewat channel tertentu sepanjang waktu kepada anggota kelompok dari suatu sistem sosial (Dewi Ariningrum Rusmiarti, 2015:88).

Melihat apa yang disampaikan oleh Rogers itu, maka dapat dimengerti, jika sebuah inovasi harus berjalan melalui sebuah media tertentu dan terus menerus kepada sebuah anggota daripada kelompok sosial dari sistem-sistem sisoal tertentu. 10 Sebenarnya, apa yang dikemukakan oleh Rogers tersebut nampak bermakna sempit. Namun konsep inovasi, yang mengaharuskan dikemukakan melalui suatu media tertentu memberikan pemahaman yang lebih jelas dan terarah. Hal ini juga memberikan isyarat jika sebuah inovaso memang harus dapat disalurkan. Jika penjelasan itu ditarik untuk melihat fenomena dakwah dalam kubur, maka dapat dijelaskan, bahwa dakwah dalam kubur memang

${ }^{10}$ Rusmiati, Dewi Ariningrum. 2015. Analisis Difusi Inovasi dan Pengembangan Budaya pada Kerja Organisasi Birokrasi, Jurnal Masyarakat telematika dan infirmasi, Vol 6 No 12 
merupakan salah satu inovasi. Hal itu tak lepas dari apa yang dikemukakan oleh Rogers, bahwa dakwah dalam kubur juga dilakukan melalui media tertentu, yaitu media kubur.

Kendati demikian, melihat penjelasan yang disampaikan oleh Rogers itu, dapat diklasifikasi empat elemn pokok sebuah inovasi. Yaitu Inovasi, Saluran Komunikasi, Jangka Waktu, dan Sistem Sosial. Inovasi berarti produk sebuah sistem yang telah dibentuk atau dibuat. Penjelasan lainnya adalah inovasi merupakan gagasan, tindakan, atau barang yang dianggap baru oleh seseorang. Kebaruan inovasi itu diukur secara subjektif, menurut pandangan individu yang menangkapnya (Dewi Ariningrum Rusmiarti, 2015:88). Kemudian produk tersebut harus disampaikan melalui saluran komunikasi tertentu dan memiliki keterbatasan waktu tertentu, yang berpengaruh terhadap suatu sistem sosial.

Berikut Tabel Elemen Divusi Inovasi yang dikemukakan oleh Rogers dan penjelasannya terhadap Dakwah Dalam Kubur. ${ }^{11}$

\begin{tabular}{|c|c|c|c|}
\hline $\begin{array}{l}4 \text { Elemen Divusi } \\
\text { Inovasi }\end{array}$ & $\begin{array}{l}\text { Penjelasan } 4 \\
\text { Elemen }\end{array}$ & $\begin{array}{l}\text { Dakwah Dalam } \\
\text { Kubur }\end{array}$ & $\begin{array}{l}\text { Penjelasan } 4 \\
\text { Elemen Divusi } \\
\text { Inonovasi pada } \\
\text { Dakwah dalam } \\
\text { Kubur }\end{array}$ \\
\hline Inovasi & $\begin{array}{l}\text { Ide, gagasan, produk } \\
\text { yang dianggap baru, } \\
\text { baik oleh individu } \\
\text { atau kelompok }\end{array}$ & $\begin{array}{l}\text { Dakwah dalam } \\
\text { kubur merupakan } \\
\text { penggabungan } \\
\text { dua metode } \\
\text { dakwah, yaitu } \\
\text { ceramah dan } \\
\text { drama yang } \\
\text { digabungkan. }\end{array}$ & $\begin{array}{l}\text { Metode } \\
\text { penggabungan } \\
\text { antara ceramah } \\
\text { dan drama } \\
\text { merupakan hal } \\
\text { yang baru. } \\
\text { (Penilaian } \\
\text { kebaruan bersifat } \\
\text { subjektif) }\end{array}$ \\
\hline $\begin{array}{l}\text { Saluran } \\
\text { Komunika }\end{array}$ & $\begin{array}{l}\text { Alat untuk } \\
\text { menyampaikan } \\
\text { pesan-pesan inovasi } \\
\text { dari sumber ke } \\
\text { penerima atau suatu } \\
\text { proses di mana } \\
\text { orang yang terlibat } \\
\text { di dalamnya } \\
\text { menciptakan dan } \\
\text { berbagi informasi } \\
\text { satu sama lain agar } \\
\text { terdapat penyamaan }\end{array}$ & $\begin{array}{l}\text { Pesan dakwah } \\
\text { disampaikan oleh } \\
\text { pendakwah di } \\
\text { dalam tanah } \\
\text { kubur melalui } \\
\text { saluran mikrofon } \\
\text { menuju pengeras } \\
\text { suara. }\end{array}$ & $\begin{array}{l}\text { Pesan dakwah } \\
\text { dalam hal ini } \\
\text { kematian } \\
\text { dipresepsikan } \\
\text { sama oleh } \\
\text { pendakwah dan } \\
\text { jamaah. }\end{array}$ \\
\hline
\end{tabular}

11 Larasati, Teori Difusi Inovasi Menurut Everett M. Rogers, (Makalah dalam http;//www.academia.edu/17890477/teori_difusi_inovasi. 2019 


\begin{tabular}{|c|c|c|c|}
\hline & $\begin{array}{l}\text { persepsi (Dewi } \\
\text { Ariningrum } \\
\text { Rusmiarti, 2015:88). }\end{array}$ & & \\
\hline Jangka Waktu & 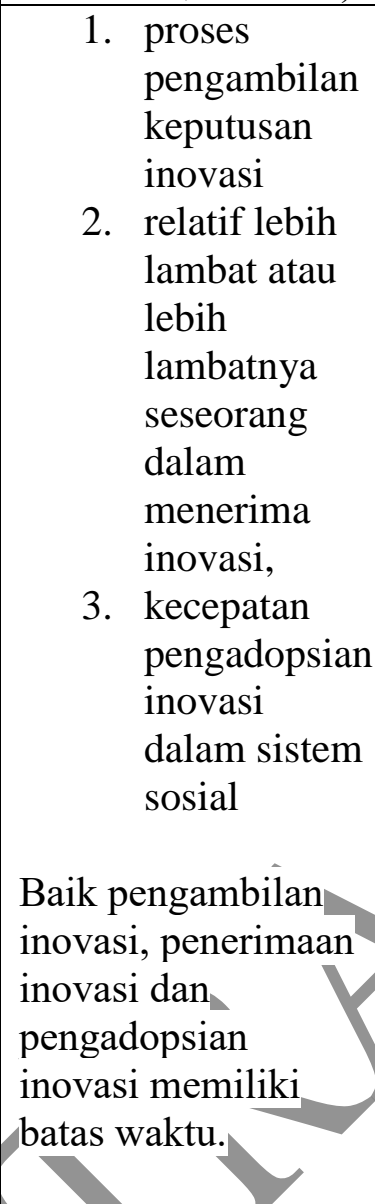 & $\begin{array}{l}\text { Proses } \\
\text { pengambilan } \\
\text { keputusan dakwah } \\
\text { dalam kubur oleh } \\
\text { pelaku dakwah } \\
\text { Penerimaan } \\
\text { dakwah dalam } \\
\text { kubur sebagai } \\
\text { salah satu inovasi } \\
\text { cenderung bersifat } \\
\text { lambat. } \\
\text { Relatif tak banyak } \\
\text { yang } \\
\text { menggunakan } \\
\text { metode dakwah } \\
\text { dalam kubur } \\
\text { sebagai metode } \\
\text { dakwah }\end{array}$ & $\begin{array}{l}\text { Pelaku dakwah } \\
\text { dalam kubur } \\
\text { memiliki batas } \\
\text { waktu dalam } \\
\text { memutuskan } \\
\text { menggunakan } \\
\text { metode itu } \\
\text { Terjadi } \\
\text { keterlambatan } \\
\text { dalam memahasi } \\
\text { metode dakwah } \\
\text { dalam kubur } \\
\text { sebagai salah satu } \\
\text { inovasi } \\
\text { Proses dakwah } \\
\text { dalam kubur } \\
\text { mulai terlihat } \\
\text { berkurang, } \\
\text { semetantara hanya } \\
\text { beberapa Ustaz } \\
\text { atau kiai saja yang } \\
\text { menggunakan } \\
\text { metode itu }\end{array}$ \\
\hline tem Sc & $\begin{array}{l}\text { Serangkaian bagian } \\
\text { yang saling } \\
\text { berhubungan untuk } \\
\text { mencapai tujuan } \\
\text { umum (Zara } \\
\text { Larasati, Teori } \\
\text { Difusi Inovasi } \\
\text { Menurut Everett M. } \\
\text { Rogers:2019). }\end{array}$ & $\begin{array}{l}\text { Pendakwah dan } \\
\text { Jamaah (Da'i dan } \\
\text { Mad'u) terikan } \\
\text { sebagai salah satu } \\
\text { sistem sistem } \\
\text { sosial dalam } \\
\text { tataran agama }\end{array}$ & $\begin{array}{l}\text { Memiliki tujuan } \\
\text { yang sama } \\
\text { terutama dalam } \\
\text { mencapai } \\
\text { kebaikan yang } \\
\text { bersandarkan } \\
\text { pada aturan } \\
\text { agama } \\
\text { (Mengingat } \\
\text { Kematian) }\end{array}$ \\
\hline
\end{tabular}

Dalam tabel di atas dapat diketahui, bahwa dalam dakwah dalam kubur merupakan sebuah inovasi dalam dakwah. Penjelasan ini bersifat subjektif kepada siapa saja yang memandangnya sebagai sebuah inovasi, baik pada individu maupun kelompok. Artinya, bahwa dakwah dalam kubur merupakan hal yang baru atau tidak, penentuannya adalah kesubjektifitasannya. Sementara pada 
tataran saluran komunikasi, dakwah dalam kubur dilakukan dari satu individu (Pendakwah) kepada khalayak (Jamaah) melalui saluran mikrofon. Dalam prosesnya, pendakwah lebih dominan untuk memberikan maksud dan presepsi yang sama kepada jamaah. Hal ini mungkin menjadi salah satu yang terlemah dalam sebuah inovasi. ${ }^{12}$

Sementara pada elemen jangka waktu, dakwah dalam kubur nampaknya menjadi salah satu hal yang sangat kuat dalam prosesnya. Hal ini bisa dilihat bagaimana proses dakwah dalam kubur saat ini. Dalam lima tahun terakhir, penerapan metode ini cenderung semakin menurun. Artinya, inovasi metode ini memiliki jangka waktu yang terbatas. ${ }^{13}$ Sementara pada sistem sosial, pendakwah dengan jamaah menjadikan sistem sosial itu terbentuk. Keduanya menjadi subjek dan objek menuju proses kebaikan. Pada proses peninjauan ini, proses dakwah dalam kubur secara sederhana memang dapat dikategorikan sebagai inovasi dalam dakwah. Sebab, elemen-elemen difusi inovasi rupanya dapat digunakan untuk melihat sejauh mana dakwah dalam kubur menjadi salah satu gagasan sebuah inovasi dalam dakwah.

\section{Islam Memandang Inovasi}

Islam selalu memandang umatnya untuk terus bergerak melakukan sebuah inovasi. Hal itu dapat dilihat secara eksplisit maupun implisit di dalam beberapa teks Hadist dan Al Qur'an. Misalnya saja dalam surat Al Ra;d ayat 13 yang berbunyi : Innallaha la yugayyiru ma biqaumin hatta yugayyiru mm bi anfusihim. ${ }^{14}$ Artinya, sesungguhnya Allah tidak akan mengubah keadaan suatu kaum sebelum mereka mengubah keadaan diri mereka sendiri (https://litequran.net/ar-rad, 2019).

Petikan ayat di atas secara implisit memberikan penjelasan, bahwa kita manusia memiliki andil untuk turut serta mengubah dan memberikan perubahan. Dalam hal ini berarti manusia memiliki andil dalam mengubah dirinya sendiri dan orang lain. Artinya, manusia dituntut untuk terus bergerak melakukan hal-hal baru, disinilahy kemudian gagasan inovasi itu muncul. Sementara itu, Quraish Shihab dalam menerjemahkan surat tersebut dalam tafsir Al-Misbah sebegai berikut :

"Sesungguhnya Allah tidak mengubah keadaan suatu kaum

12 J. Cresswell. Research Design: Qualitative Research for Education, Thousand Oaks, CA: Sage Publications. 1998

${ }^{13}$ Faizin, Muhammad, Unik Mubaligh ini Berdakwah dari Dalam Kubur. 2019

14 Al-Khanif, Muhammad Fadli. (2019). Telaah Innallaha La yugayyiru ma biqaumin hatta yugayiru ma bi anfisihim, Qs Al Ra'd (13):11 Meurut Ahli Tafsir, Universitas Muhammadiyah Surakarta 
sehinga mereka mengubah apa yang ada pada diri mereka”.

(Muhammad Fadli Al-Khanif, 2019:2)

Menurut At-Thabari, seperti dikutip dalam NU Online, maksud dari ayat tersebut justru menjelaskan, bahwa semua orang itu dalam kebaikan dan kenikmatan. Menurut At-Thabrani, Allah tidak akan mengubah kenikmatankenikmatan seseorang kecuali mereka mengubah kenikmatan menjadi keburukan, sebab perilakunya sendiri dengan bersikap zalim dan saling bermusuhan kepada saudaranya sendiri. (Ahmad Mundzir, 2019). Melihat penjelasan tersebut, bahwa dapat disimpulkan, segala yang kita lakukan berdampak pada akibat setelahnya. Untuk itu, ayat tersebut seakan menuntut kita agar dapat melakukan hal-hal yang positif dan baik, sehingga hasil atau akibat dari apa yang dilakukan akan menjadi baik. Sementara masih dalam sumber yang sama, Imam A1-Qurthubi dalam tafsirnya menjelaskan sebagai berikut:

"Sesungguhnya Allah tidak mengubah keadaan sesuatu kaum sehingga mereka mengubah keadaan yang ada pada diri mereka sendiri." Dalam ayat ini Allah member tahu bahwa Ia tidak mengubah suatu kaum sehingga ada salah satu di antara mereka ada yang mengubahnya. Bisa jadi dari golongan mereka sendiri, pengamat, atau faktor penyebab yang masih mempunyai hubungan sebagaimana para pasukan yang dikalahkan pada saat perang Uhud disebabkan penyelewengan yang dilakukan oleh ahli panah. Demikian pula contoh-contoh dalam syari'at. Ayat ini tidak mempunyai arti bahwa kekalahan perang Uhud murni disebabkan perilaku dosa seseorang, tapi terkadang musibah-musibah itu turun disebabkan oleh dosanya orang lain sebagaimana sabda Nabi Muhammad ketika ditanya salah seorang "Wahai Rasul, apakah kita akan mengalami kehancuran sedangkan di antara kita ada yang shalih?" Jawab Nabi "Ya, jika ada banyak pelaku zinanya”. (Ahmad Mundzir, 2019).

Penjelasan demi penjelasan para ahli tafsir pada ayat di atas memberikan gambaran, bahwa dalam kontek dakwah, berhasil atau sukses tidaknya sebuah dakwah bergantung sejauh mana proses kita berdakwah itu berjalan. Untuk itulah inovasi, kreatifitas dakwah sangat diperlukan. Ada banyak kisah sebuah inovasi dalam islam yang kemudian berkembang menjadi hal yang berguna hingga saat ini. Misalnya saja menyangkut kebersihan badan seperti penggunaan sikat gigi.

"Islam adalah agama pertama yang menempatkan penekanan khusus pada kebersihan tubuh. Dalam Al-Qur'an juga terdapat banyak petunjuk untuk ritual membersihkan tubuh. Tak heran pada kebersihan mulut pun menjadi suatu yang penting dikalangan masyarakat Islam. Masyarakat Mesir diakui telah mengunyah ranting-ranting pohon untuk 
kebersihan mulut sebelumnya. Namun Ranting yang berasal dari pohon Miswak ini, mulai terkenal saat Nabi Muhammad SAW mengunyah ranting tersebut secara teratur. Walaupun demikian ranting pohon Miswak tidak disebutkan dalam Al-Qur'an, hanya saja ranting ini sering disebutkan dalam jurnal-jurnal cendikiawan Muslim”. (Atika Nursya Puteri, 2016).

Melihat bagaimana tradisi membersihkan gigi menggunakan ranting-rantin pohon kini telah berkembang menjadi sikat gigi. Hal tentu dalam prosesnya ada sebuah inovasi-inovasi yang terus tumbuh. Dari satu jenis pasta gigi menjadi beberapa jenis pasta gigi. Itu artinya islam juga memiliki andil yang cukup besar dalam peradaban dunia. Hal ini secara tidak langsung menjadi salah satu dakwah yang cukup berhasil. Tentu inovasi dan adobsi terhadap sebuah ide atau gagasan tersebut berlangsung cukup lama dan terus dikembangkan oleh umat manusia.

Sebenarnya, dalam Ajaran Islam itu terbagi menjadi dua, yaitu ada yang tsabit (tetap) atau qathi, dan ada yang dinamis inovatif, yaitu mutaghayir atau ijtihadi. (Ibnu Nawawi, 2019). Dalam konteks dakwah, tentu hal ini merupakan salah satu yang bersifat dinamis inovatif. Hal seiring dengan perkembangan zaman. Jika melihat topik artikel ini, mengenai dakwah dalam kubur, tentu hal ini bagian dari pada hal yang dinamis dan inovatif. Sebab dakwah sejatinya harus dilakukan melalui cara-cara yang terus mengikuti perkembangan zaman. Walaupun saat ini dakwah dalam kubur sudah tak lagi sering dilakukan seperti sedia kala, perlu kiranya ada sentuhan-sentuhan baru. Sehingga dakwah tetap hidup dan berkembang.

Jika menoleh pada masa Walisongo dalam menyebarkan agama islam di Indonesia, tentu ada banyak inovasi dalam dakwah yang dilakukan. Mulai menggunakan perkawinan, perdagangan, budaya hingga cara bersosialnya. Misalnya, saja pendekatan Psikosufistik yang digunakan oleh Walisongo telah mampu memberikan corak dakwah komunikasi yang efektif. Seperti yang dijelaskan oleh Yuliyatun Tajuddin, bahwa dengan pola komunikasi tersebut akan membangun kesadaran spiritual-relijius umat dan pada akhirnya akan membangun kesadaran untuk lebih mendekatkan diri kepada Allah Jalla Jalaluhu. (Yuliyatun Tajuddin, 2014:388).

\section{Perlunya Inovasi Di Era Millenial}

Memasuki era milenial tentu bukan barang mudah. Ada banyak kebiasan, budaya terus berkembang. Hal itu bukan tanpa alasan, seluruh perkembangan teknologi serta arus informasi yang terus menerus menerpa menjadikan salah satu penyebab perubahan gaya hidup dan berfikir masyarakat menjadi terus berkembang. Dalam buku profil generasi milenial Indoensia, tentang statistik 
gender tematik yang diterbitkan oleh hasil kerjasama antara kementerian pemberdayaan perempuan dan anak, dengan badan pusat statistik yang mengutip hasil studi yang dilakukan oleh Boston Consulting Group (BCG) bersama University of Berkley tahun 2011 di Amerika Serikat tentang generasi milenial USA menjelaskan, bahwa ada sedikitnya empat ciri generasi milenial.

Pertama, minat membaca secara konvensional kini sudah menurun karena Generasi Y lebih memilih membaca lewat smartphone mereka. (Indah Budiati dkk, 2018:19). Itu artinya, generasi milenial lebih menyukai hal-hal baru yang berhubungan dengan teknologi. Pola budaya seperti ini nampaknya bukan hanya terjadi di Amerika, namun juga sudah dapat dirasakan di Indonesia. Kedua, millennial wajib memiliki akun sosial media sebagai alat komunikasi dan pusat informasi. (Indah Budiati dkk, 2018:19). Pada ciri yang kedua ini, lagi-lagi teknologi menjadi salah satu unsur yang selalu melekat pada generasi milenial. Artinya, teknologi sudah tak dapat dilepaskan dari kehidupan generasi milenial. ${ }^{15}$

Ketiga, millennial pasti lebih memilih ponsel daripada televisi. Menonton sebuah acara televisi kini sudah tidak lagi menjadi sebuah hiburan karena apapun bisa mereka temukan di telepon genggam. (Indah Budiati dkk, 2018:19). Ciri yang ketiga ini juga sama, menepatkan teknologi pada sendi-sendi kehidupan kaum milenial. Ini semakin menambah kuat bagaiama milenial tak dapat ditinggalkan dari perkembangan teknologi. Tentu hal itu akan menambah kesadaran manusian, bahwa zaman telah benar-benar berubah. Hal itu dapat ditandai dengan banyaknya generasi yang tumbuh, atau biasa disebut dengan bonus demografi.

Keempat, millennial menjadikan keluarga sebagai pusat pertimbangan dan pengambil keputusan mereka. (Indah Budiati dkk, 2018:19). Corak yang ketiga ini menampatkan keluarga sebagai salah satu yang masuk dalam sendi-sendi kehidupan mereka dalam berumah tangga. Hal ini menjadi salah satu hal baru yang dapat menjadi salah satu pertimbangan dalam menilai milenial. Bahwa mereka rupanya sangat dekat dengan keluarga. 'perbedaan cora-corak semacam ini sedikit membuka wawasan jika milenial sebenarnya memberikan porsi terhadap keluarga.

Kendati demikian, tiga corak millenial lainnya lebih banyak menyentuh pada kedekatan millenial pada teknologi. hal ini menjadi salah satu hal yang dapat dimaklumi. Sebab Salah satu fenomena penting proses globalisasi telah melahirkan generasi gadget, istilah yang digunakan untuk menandai munculnya generasi millennial. (Heru Dwi Wahana, 2015:14-22). Maka dengan demikian, kedekatan millenial pada teknologi adalah salah satu konsekuensi kondisi yang

${ }^{15}$ Habibi, Muhammad, Optimalisasi Dakwah Melalui Media Sosial di era Millenial, Jurnal Al-Hikmah: Jurnal Dakwah, Volume 12, Nomor 1. 
mengiringinya. Jika sudah begitu, maka perlu ada penyesuaian-penyesuaian dalam dakwah yang dilakukan. Terutama menyangkut metode yang digunakan.

Hal itu sebagai konsekuensi yang harus diterima seiring dengan perubahan-perubahan yang terjadi di dalam masyarakat. Dakwah harus mengikuti perkembangan zaman yang ada. Maka cara berdakwah memerlukan inovasi serta kreatifitas-kreatifitas baru. Revolusi media informasi telah membawa manusia pada babak baru, dimana manusia tidak lagi khawatir dengan jarak ketika berkomunikasi dengan sesamanya. (Moch. Fakhrurroji, 2019:121). Maka jika sudah begitu, dakwah harus lebih cerdas. Dakwah tidak bisa lagi dilakukan dengan cara-cara yang konvensional. Perlu ada perubahan dengan melompat jauh pada hal-hal yang benar-benar baru.

Setidaknya, ada empat yang bisa dilakukan oleh para pelaku dakwah, dalam melaksanakan dakwahnya di era kontemporer seperti saat ini. Hal tersebut dikemukakan oleh Abdul Basit mengenai dakwah cerdas di era modern. Di antaranya adalah:

"Menjadikan dakwah sebagai objek ilmu yang dapat diteliti dan dikembangkan sesuai dengan kebutuhan dan tuntutan masyarakat. mengubah paradigma ilmu dakwah menjadi ilmu komunikasi Islam dengan cara mensintesiskan teoriteori ilmu komunikasi dengan teori-teori dakwah yang bersumber dari ajaran Islam. Menyiapkan da'i yang mampu beradaptasi dengan perkembangan IPTEK, dan memanfaatkan berbagai media komunikasi dan informasi yang banyak dipergunakan oleh masyarakat". (Abd Basit, 2013:76).

Empat hal tersebut nampaknya bisa menjadi sandaran bagaimana sebuah inovasi dakwah dapat dilakukan. Yaitu dengan cara memperhatikan keempat item tersebut. Terutama kaitannya dengan teknologi. Dakwah saat ini memang harus mélibatkan unsur teknologi. Sebab masyarakat sudah tak dapat dipisahkan dari derasnya teknologi yang terus berkembang. Belum lagi maraknya informasi yang datang setiap detiknya. Seperti apa yang dijelaskan oleh Abdul Basit, pendakwah juga hendaknya harus mampu beradaptasi dengan perkembangan ilmu pengetahuan dan teknologi. Sebab hal ini akan menjadi suatu yang tidak bisa dihindari.

\section{Dakwah Pada Millenial}

Zaman akan terus berkembang beriringan dengan nama istilah zaman itu muncul. Maka dakwah mestinya bukan hanya menepati posisi bagaimana dakwah di era millenial, akan tetapi bagaimana dakwah bisa dilakukan pada kaum 
millennial. ${ }^{16}$ Hal ini dipandang perlu mengingat, problematika pada generasi millenial juga terbilang cukup kompleks. Masalah-masalah yang dihadapi memiliki corak yang berbeda jika dibanding pada generasi sebelumnya. Dakwah pada millenial berarti melakukan optimaliasasi pada dakwah.

Salah satu titik poin mengapa harus menyasar millenial adalah lantaran Generasi ini dikenal sangat senang menghabiskan hidupnya di jejaring media daring. (Muhammad Habibi, 2018:108). Melihat kondisi millenial seperti itu, maka sudah pasti millenial memiliki problem sendiri. Kehidupannya di media sosial kerap kali memiliki masalah tersendiri dibanding yang nampak. Bahkan mereka kerap kali terlibat dalam debat kusir mengomentari informasi yang belum jelas kebenarannya. Debat tersebut biasanya berlangsung sengit, tanpa peduli dengan substansi, tanpa acuan data yang valid, menyita waktu produktif, dan seringkali berujung pada pertengkaran. (Noveliyati Sabani, 2018:96) Untuk itu, maka pendakwah harus menjadikan sasaran khusus millenial sebagai objek dakwah, mempelajari problem mereka yang kompleks untuk selanjutnya mencarikan jalan keluar, agar mereka tidak hidup dan terjebak pada masalahmasalah yang sebenarnya semu.

\section{SIMPULAN}

Dakwah dalam kubur sejatinya merupakan salah satu dakwah yang inovatif. Menggabungkan dua metode seperti ceramah dan drama ke dalam dakwah membuat masyarakat menjadi tertarik. Di luar istilah dakwah dalam kubur, harus diakui jika metode itu telah berhasil mengajak masyarakat untuk ikut menyaksikan ceramah. Keberhásilan itu juga dapat dilihat dari banyaknya masyarakat yang tersentuh hatinya bahkan sampai menangis mendengarkan pesan dakwah tentang kematian disampaikan.

Namun dalam perjalanannya, perkembangan zaman telah berubah. Kini, manusia telah diatíhkan pada permainan baru, bernama teknologi. Bersamaan dengan itu, lahirlah generasi millanial. Hidupnya selalu dekat dengan teknologi dan perkembangannya. Akibatnya, dakwah dalam kubur belum mampu menyentuh pada generasi tersebut. Sehingga inovasi dakwah dalam kubur perlu untuk dipertimbangkan kembali.

Walau tujuan dakwah adalah sama, namun pesan yang disampaikan dapat dilakukan dengan cara yang berbeda, langkah bijak yang bisa dilakukan adalah mengikuti perkembangan zaman. Memanfaatkan teknologi sebagai salah satu

${ }^{16}$ Habibi, Muhammad, Optimalisasi Dakwah Melalui Media Sosial di era Millenial, Jurnal Al-Hikmah: Jurnal Dakwah, Volume 12, Nomor 1. 
sarana atau media dakwah lebih memungkinkan untuk dilakukan. Di sisi lain, penyebarannya juga lebih luas. Namun demikian, cara apapun memerlukan sentuhan dan inovasi baru. Sehingga dakwah dapat lebih mudah ditima dan pesan dakwah dapat mudah dicerna.

\section{DAFTAR PUSTAKA}

Abidin, M. Ali Zainal, Anjuran Melaksanakan Ziarah Kubur, (https://islam.nu.or.id/post/read/37170/anjuran-melaksanakan-ziarahkubur - Diakses pada 2 Desember 2019)

Al-Khanif, Muhammad Fadli. (2019). Telaah Innallaha la yugayyiru ma biqaumin hatta yugayyiru ma bi anfusihim, Qs Al Ra'd (13):11 Menurut Ahli Tafsir, Universitas Muhammadiyah Surakarta.

Arief, Saiful, Satu Setengah Jam Gus Nur Berdakwah dari Dalam Kubur, (https://faktualnews.co/2017/05/23/satu-setengah-jam-gus-nurberdakwah-kubur/15228/ - Diakses pada 1 Desember 2019).

Aziz, Abd. (2018). Ziarah Kubur, Nilai Didaktis dan Rekonstruksi Teori Pendidikan Humanistik, (Jurnal Episteme, Vol. 13, No 1, Juni

Basit, Abdul. 2013. Dakwas Cerdas di Era Modern, Jurnal Komunikasi Islam, Volume 03, Nomor 01, Juni

Faizin, Muhammad, Unik, Mubaligh Ini Berdakwah dari Dalam Kubur, (https://www.nu.or.id/post/read/104176/unik-mubaligh-ini-berdakwahdari-dalam-kubur, diakses pada 11 Desember 2019)

J. Cresswell. (1998). Research Desig: Qualitative Research for Education, Thousand Oaks, CA: Sage Publications.

Wahidmurni. (2017). Pemaparan Metode Penelitian Kualitatif, Makalah Dosen Fakultas Ilmu Tarbiyah dan Keguruan, UIN Maulana Malik Ibrahim Malang, Juli

Grove, S.K, Burns, N. (1993). The practice of nursing research: Conduct, critique \& utilization ( 2 nd. Ed). (Philadelphia: W.B. Saunders Company.

Fakhrurroji, Moch. (2010). Dakwah dan Inovasi Media, Peluang dan Ancaman Media Global Atas Dakwah Islam, Jurnal Komunika, Vol 4, No. 1, JanuariJuni.

Habibi, Muhammad. (2018). Optimalisasi Dakwah Melalui Media Sosial di Era Millenial, Jurnal Al-Hikmah: Jurnal Dakwah, Volume 12, Nomor 1. 
https://litequran.net/ar-rad - Diakses pada 3 Desember 2019

Indah Budiat dkk. (2018). Statistik Gender Tematik : Profil Generasi Milenial Indoensia, Kementerian pemberdayaan perempuan dan anak serta badan pusat statistik, November.

Larasati, Zara, Teori Difusi Inovasi Menurut Everett M. Rogers, (Makalah dalam https://www.academia.edu/17890477/TEORI_DIFUSI_INOVASI - Diakses pada 3 Desember 2019)

Mesiono, Syafaruddin, Asrul. (2012). Inovasi Pendidikanm Suatu Analisis Terhadap Kebijakan Baru Pendidikan, Medan, Perdana Publishing.

M Rogers, Everett. 1983. Diffutions of innovations. 3rd Edition. New York: The Free Pass A Division of Macmillan Publishing Co, Inc.

Mundzir, Ahmad, Tafsir Ar-Ra'd Ayat 11 : Motivasi Mengubah Nasib?, (https://islam.nu.or.id/post/read/112873/tafsir-ar-ra-d-ayat-11--motivasimengubah-nasib- - Diakses pada 4 Desembar 2019)

Nawawi, Ibnu, Islam Anjurkan Pemeluknya Lakukan Inovasi dalam Beragama, (https://www.nu.or.id/post/read/111814/islam-anjurkan-pemeluknyalakukan-inovasi-dalam-beragama- - Diakses pada 5 Desember 2019)

Pengertian Inovasi dan 8 Hal Penting Menjadi Inivatif, (https://www.studilmu.com/blogs/details/pengertian-inovasi-dan-8-halpenting-menjadi-inovatif - Diakses 2 Desember 2019).

Puteri, Atika Nursya, 8 Inovasi Peradaban Muslim Ini Membantu Umat Manusia, (https://dunià.tempo.co/rêad/786233/8-inovasi-peradaban-muslim-inimembantu-umat-manusia/full\&view=ok - Diakses pada 4 Desember 2019)

Roifa, Desy Ana. (2018). Dakwah dalam Kubur, Studi Fenomenologis Metode Dakwah Kiai Mohaedi Anwar, Skripsi UIN Walisongo Semarang.

Rusmiarti, Dewi Ariningrum. 2015. Analisis Difusi Inovasi dan Pengembangan Budaya pada Kerja Organisasi Birokrasi, Jurnal masyarakat telematika dan informasi, Vol 6 No 12, November

Sabani, Noveliyati. (2018). Generasi Milenial dan Absurditas Debat Kusir Virtual, (Jurnal Informasi Kajian Ilmu Komunikasi, Volume 48, No. 1, Juni.

Tajuddin, Yuliyatun. (2014). Walisongo Dalam Strategi Komunikasi Dakwah, Jurnal Addin, Vol. 8, No. 2, Agustus. 
Wahana, Heru Dwi. (2015). Pengaruh Nilai-Nilai Budaya Generasi Millennial Dan Budaya Sekolah Terhadap Ketahanan Individu (Studi Di SMA Negeri 39, Cijantung, Jakarta), Jurnal Ketahanan Nasional, XXI (1), April.

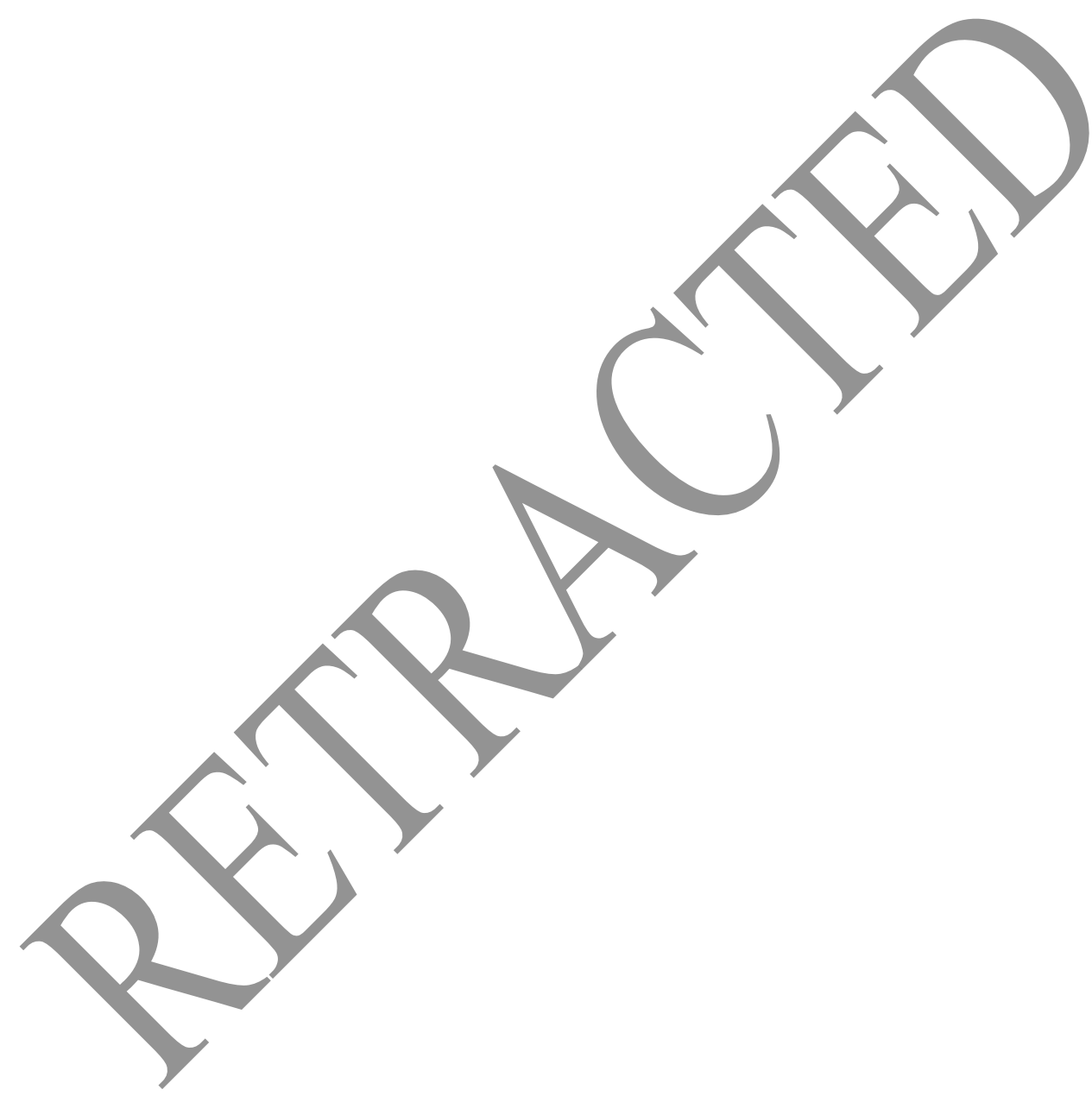

